\title{
IGBO ADJECTIVES AS MORPHOPHONOLOGIZED RELATIVES
}

\author{
Omen N. Maduka-Durunze \\ Imo State University
}

\begin{abstract}
Igbo adjectives are semantically, syntactically and morphophonologically derived. Underlyingly, they are relatives that are phonologized into a suppletive form. For this reason they cannot occur in predicative position, unlike adjectives in English. They are in two sets: the relative, polar set, which can be emphasized and further suppleted, and the non-relative, antipodal or taxonomic set, which cannot be emphasized, except perhaps by way of ideophonic periphrasis. Non-emphatic adjectives are also often ambiguous because of their inevitable incorporation of two copulas, one stative and neutral, the other active and cognate. One implication of all this is that 'Adj' is not a primitive syntactic category in Igbo and as such is not needed for its formal description. Another is that on the basis of formal behavioural criteria, a proper census of true adjectives in Igbo can now be taken.
\end{abstract}

\section{Introduction}

The class of Igbo adjectives is a limited one, with only five basic elements which include the following: oma 'good', 'beautiful', 'handsome'; ojọọ 'bad', 'ugly'; ocha 'white', 'bright'; ojī 'black', 'dark'; and a rather suspect one, ukwu 'big', 'large' (see Emenanjo [1978]). Other non-basic forms are omaricha (emphatic form of oma), njokiri (emphatic form of ojọō), ajọ (a slightly stronger form of ojọ̄), and nnukwuru or nnukwu (emphatic form of $u k w u$ ) Some of the non-basic forms such as omaricha are dialectal while the basic forms are general.

\section{Phonological Derivation of Adjectives}

The following table sets out the phonological derivation of adjectives from verb roots through their cognate noun forms. (No attempt is made to formalize this with rules as that would go beyond the scope of this paper): 


\begin{tabular}{|c|c|c|c|}
\hline verb root & cognate noun & basic adjective & emphatic adjective \\
\hline$-m a-$ & $m m a$ & ọma & omaricha \\
\hline -jọ- & njọ & ojọọ & ajọ/njọịiri \\
\hline -cha- & ọcha & ocha & - \\
\hline$-j i-$ & òji & ojīi & ----- \\
\hline$?$ & ukwuù & $u k w u$ & nnukwu(ru) \\
\hline
\end{tabular}

Many patterns are extractable from this list, but the most interesting observation to make is that the adjectives ocha and ojii have no emphatic alloforms. This fact is accounted for later in this paper. Also, $u k w u$ has no identifiable verb-root source.

\section{Adjectives in Associative Construction}

An associative construction is one in a non-predicative form in which a modification is made of a head such that the modification is associated with it. It is an important fact of Igbo adjectives that they only occur in associative construction, unlike adjectives in English which can also occur in predicative constructions.

3.1. Basic forms in Associative Construction. Descriptive words in Igbo normally occur in post-nominal position in associative constructions, as the basic adjectives in the following:

(1) a. nwany!̀ ọma

'beautiful/good woman'

b. *ọma nwanỵ̣

(2) a. nwanyı̀ ojọọ̄

'ugly/bad woman'

b. *ojọọ̄ nwanỵ̣

(3) a. akwà ọcha

'white/bright cloth'

b. *ọcha akwà

(4) a. akwà ojī

'black/dark cloth'

b. *ojī akwà

(5) a. ụlọ $u k w u$

'large house'

b. *ukwu ụlọ

Nothing normally intervenes between head and adjectival modifier except in a singular situation such as the following: 
(6) nwanỵ̣ ǹkè ọma

(7) ụlọ ǹkè ọcha '(selected) woman who is beautiful/good'

'(selected) house which is white/bright'

The particle nkè is one which distinguishes without pointing. In other words, $\grave{n} k e$ makes non-deictic reference. Its behaviour is different from ahụ 'that', and à 'this' which do make deictic reference:

(8) nwanỵ̀ ọma à

(9) nwanỵ̀ ọma ahụ 'this beautiful/good woman'

'that beautiful/good woman'

However, while the basic and adjectival forms occur only post-nominally, some other nominal modifiers occur both post-nominally and pre-nominally, as is the case with the elements Emenanjo [1978] terms "qualifactive nouns", e.g. ogologo 'long', 'tall', mkpumkpu 'short', abadaba 'broad', etc.

(10) nwokē ogologo à

(11) ogologo nwokē à

(12) ụlọ mkpụmkpụ à

(13) mkpụmkpụ ụlọ à 'this tall man'

'this tall man (emphatic)'

or 'the tallness of this man'

'this short house'

'this short house (emphatic)'

or 'the shortness of this house'

When qualifactive nouns precede their head nouns they become emphatic in their descriptive meaning or ambiguously suggest an inherent as opposed to a descriptive meaning. This can be illustrated using tree-diagrams as follows:

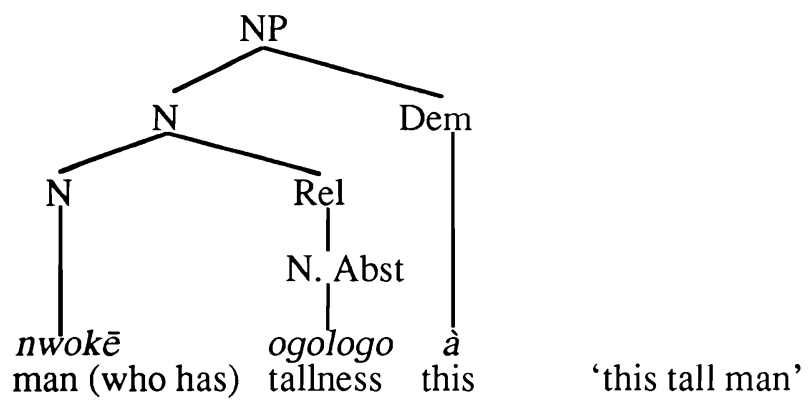


(15)

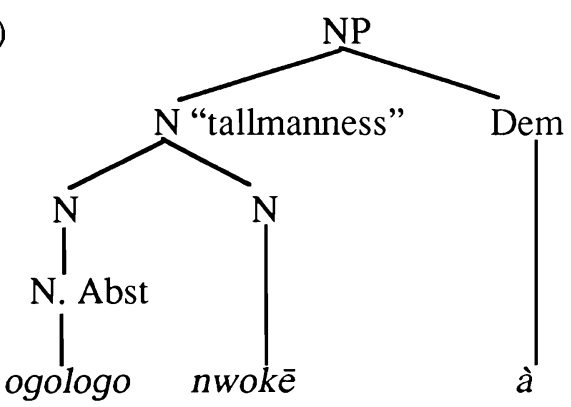

(type of) tallness man this 'this tall man (emphatic)'

(16)

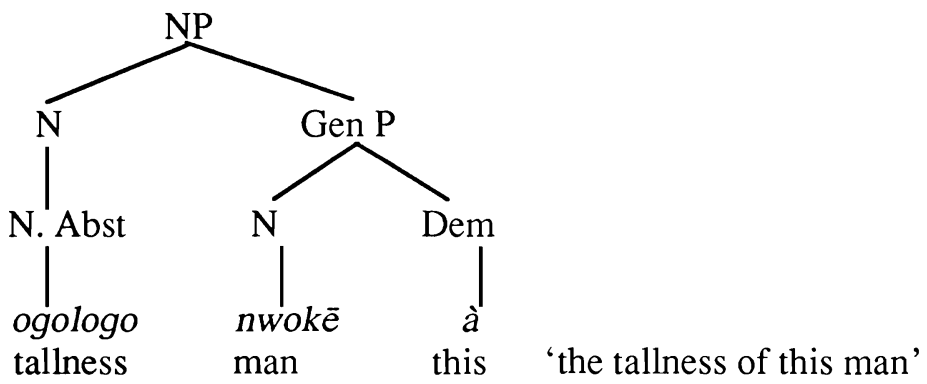

From the diagrams above, it is clear that the ambiguity in the construction ogologo nwoke à derives from its two possible underlying tree-structures (15) and (16).

We thus conclude that while adjectives in their basic forms cannot be preposed, qualifactive nouns may be preposed, in which case they become more emphatic.

3.2. Non-Basic forms in Associative Construction. Just as basic forms occur in post-nominal position, non-basic forms, when they exist in dialects, occur normally in the pre-nominal position, or, in rare usage, in the post-nominal position. As stated earlier, non-basic forms are emphatic. They therefore behave like qualifactive nouns except for the fact that even when they occur in post-nominal position they still carry emphasis:

(17) a. omarịcha nwanỵ̄ à

'this pretty woman (emphatic)'

b. nwanỵ̀ ọmaricha à

(but rare)

(18) a. njọkịi ụlọ ahụ̀

'that ugly house (emphatic)'

b. ụlọ njọkịịi ahụ

,

(but rare) 
(19) a. nnukwu ụlọ ahụ

b. ụlọ̀ nnukwu ahụ 'that large house (emphatic)'

(but rare)

It is quite interesting to observe that ocha 'white', 'bright' and ojī 'black' 'dark' have no emphatic, non-basic forms. The words ocha and ojī are in absolute or antipodal/taxonomic opposition, while oma and ojọ̄ are in relative or gradeable, polar opposition. In antipodal or taxonomic opposition, the opposing elements have their positions firmly fixed at extremes in such a way that an inherent emphasis would be redundant. In gradeable, polar opposition, on the other hand, positions are so fluid that one can always emphasize. Norms are relative, depending on speakers' encyclopaedic knowledge of the element of description within the universe of discourse. The other item, $u k w u$ 'big, large', is also gradeable even though we do not have any member in opposition with it. 1

\section{Semantic Derivation of Adjectives}

4.1. Basic forms. That adjectives are phonologically derived from nouns or their cognate verbs is clear enough from their phonological shape (see $\S 1$ ); but more importantly, they are also derived from them semantically. Specifically, the adjective is derived from a relativized predicate incorporating its cognate noun, as illustrated below:

\begin{tabular}{|c|c|c|c|c|}
\hline (20) $\begin{array}{l}u \text { ụlò } \\
\text { house }\end{array}$ & $\begin{array}{l}\text { ahụ̀ } \\
\text { that }\end{array}$ & $\begin{array}{l}d \dot{1} \\
\text { possesses }\end{array}$ & $\begin{array}{l}\text { mmā } \\
\text { goodness }\end{array}$ & 'that house is good' \\
\hline $\begin{array}{l}\text { 1) ụlọ } \\
\text { house }\end{array}$ & $\begin{array}{l}\text { ahụ } \\
\text { that }\end{array}$ & $\begin{array}{l}d_{1} \\
\text { that-possesses }\end{array}$ & $\begin{array}{l}m m a \bar{a} \\
\text { goodness }\end{array}$ & 'that house that is good' \\
\hline
\end{tabular}

In these sentences $d i$ is a copula; each could go with the cognate verb mara (made up of the root $-m a$ - and the $-r \mathrm{~V}$ factitive suffix, here realized as $-r a$ ) with a slightly different result:

\begin{tabular}{|c|c|c|c|c|}
\hline $\begin{array}{l}\text { ullọ } \\
\text { house }\end{array}$ & $\begin{array}{l}\text { ahù } \\
\text { that }\end{array}$ & $\begin{array}{l}\text { màrà } \\
\text { does-beauty }\end{array}$ & $\begin{array}{l}m m \bar{a} \\
\text { beauty }\end{array}$ & 'that house is beautiful' \\
\hline & & mārā & $m m a \bar{a}$ & 'that house that is beautiful' \\
\hline
\end{tabular}

\footnotetext{
1The opposing item to $u k w u$ is the ideophonic nominal ntà or ntakiri.. This in addition to the fact that $u k w u$ has no corresponding cognate verb intensifies the suspicion that it is not an adjective.
} 
Examples (20) or (22) are sentences with mma in a predicative position; examples (21) or (23) are phrases, noun phrases, with relative clauses containing mma. Relativization in Igbo is signalled by tone change (a floating high tone steps up the preceding and following tones if they are low). Relative clause reduction involves the elision of the copula and, in the case of adjective formation, suppletion. Either (21) or (23) can be thus reduced to (24):
$\begin{array}{ll}\text { ullọ } & \text { oma } \\ \text { house } & \text { (that is) }\end{array}$
ahụ
'that beautiful/good house'

Example (24) is therefore a shorter paraphrase of (21) and (23) with oma as a suppletive form and the demonstrative postposing appropriately. In other words, oma (Adj) semantically incorporates a Relative Marker (tone change), a copula (di or mara), and the abstract noun mma. This can be stated using the following polycategorial lexical attachment format (see Gruber [1976]). ${ }^{2}$

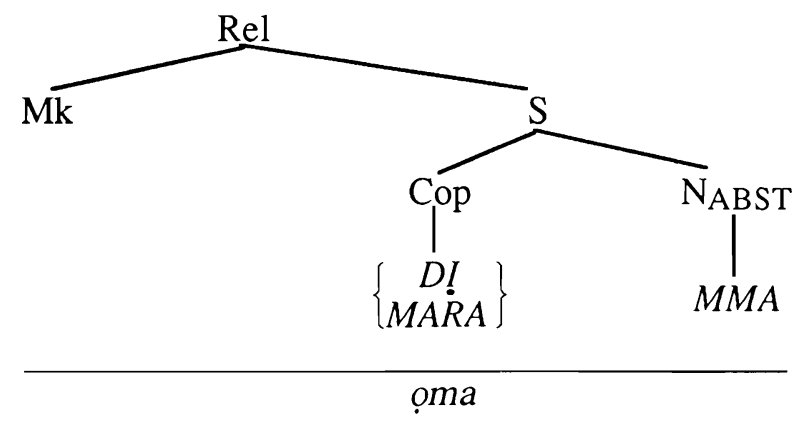

That the semantic content of oma incorporates the copular di or mara and the relative tone marker can be seen from the unacceptability of the following:
a. *ụlọ ahụ dụ ọma
b. *ụlọ ahụ dị ộmā
a. *ụlọ ahụ̀ màrà ọma
b. *ụlọ ahụ mārā ọmā

\footnotetext{
${ }^{2}$ This representational format is due to Gruber's formalization of semantic content and lexical environment and his concept of incorporation. A continuous underline enclosing categories, e.g. EMPH, implies that it is obligatorily incorporated. Enclosing brackets '( )' implies that it is optionally incorporated (see Gruber [1976]).
} 
Thus, the elements already incorporated are not permitted in the environment of oma. This accounts for Emenanjo's [1978:71] observation that "adjectives can never be used after $-d i$ 'have the qualities of ". The other basic adjectives are derived in the same way: ocha from the noun ọcha and the verbs $d i$ and chara; ojī from the noun $o j i$ and the verbs $d i$ and jiri; ojọ̄ from the noun njọ and the verbs $d i$ and joro. The exception here is the fifth member $u k w u$ which has no cognate verb and as such incorporates only the noun ukwuù and the verb $d i$.

That adjectives alternatively incorporate the copula $d i$ and the appropriate cognate copula is responsible for their inherent ambiguity as shown earlier. We may need to clarify this further. The phrase (28a) can yield either of the paraphrases $(28 b)$ and $(28 c)$ :

(28) a. nwanỵ̀ ọma ahụ

b. nwanỵ̀ ahụ dị mmā

'that good woman'

c. nwanỵ̀ ahụ mārā mmā

'that beautiful woman'

In (28b) $d i$ is selected, ultimately yielding the adjective gloss 'good'; in (28c) mara is selected, yielding 'beautiful'. Example (28a) can therefore be seen to be ambiguous. All the other adjectives except $u k w u$ are ambiguous for the same reasons, but $u k w u$ has only one meaning 'large' because it incorporates only the copula $d i$.

4.2. Non-basic forms. The semantic derivation of non-basic forms becomes clear once the derivation of basic ones is shown. As said earlier, the difference between the basic and the non-basic adjectives is in the latter's incorporation of emphasis (and their greater syntactic mobility). It does appear, however, that emphatic, nonbasic forms must incorporate one, and ony one, copula. Thus, in addition to emphasis, omaricha incorporates only mara, njokiri incorporates only joro, ajo incorporates only $d i$, and nnukwu(ru) necessarily incorporates only $d i$ These facts can be represented rather casually thus:
a. $\mathrm{Mk}+\mathrm{EMPH}+\left\{\begin{array}{c}\text { mara } \\ * \mathrm{~d} \dot{\varphi}\end{array}\right\}+m m a=\left\{\begin{array}{cc}\text { omaricha } & \text { "extremely beautiful' } \\ - & \text { "extremely good' }\end{array}\right\}$
b. $\mathrm{Mk}+\mathrm{EMPH}+\left\{\begin{array}{c}j o r o \\ d i\end{array}\right\}+n j o=\left\{\begin{array}{c}\text { njokiri } \\ \text { ajọtremely ugly' }\end{array}\right.$
c. $\mathrm{Mk}+\mathrm{EMPH}+\left\{\overline{d_{i}}\right\}+u k w u u ̀=\{n n u k w u(r u)$ 'extremely large' $\}$

A sample lexical attachment to demonstrate the semantic content of non-basic forms is shown below (full account is given in $§ 5$ ): 
(30)

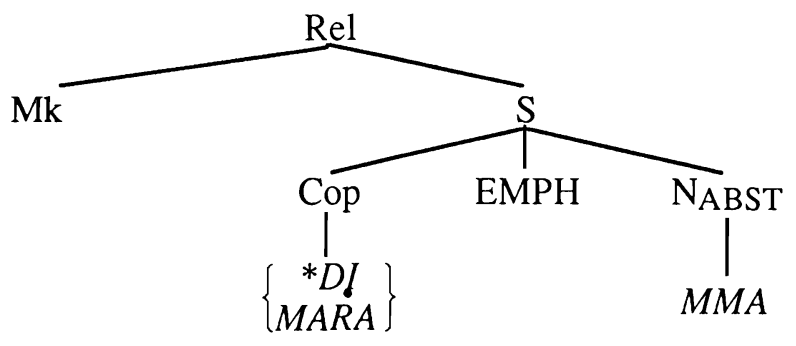

\section{omaricha}

Once again, the taxonomic colour terms ocha and ojii cannot be emphasized through suppletion. It does appear in any case that the concepts they represent can be intensified by way of some appropriate ideophonic periphrasis, as in the following sentences:

(31)

$\begin{array}{llll}o & \text { nà } & \text { àcha } & \text { fàà }\end{array} \quad$ 'it shines very brightly'

$\begin{array}{llll}o & \text { nà } & \text { èji } & \text { kpì̀ }\end{array} \quad$ 'it is very deep black or dark'

The ideophones (underlined) here function as adverbial intensifiers. It is not yet certain what the relationship is between semantic field character and ideophonic intensification. If we recognize that the two adjectives under consideration are physical (visual) while the others are mental, then we may surmise that suppletive emphasis and ideophonic intensification function in two opposing semantic field areas, the first in the mental and the second in the physical fields.

\section{Formal Syntactic Description}

A fragment of Igbo grammar that would conveniently handle the observations made is given below. The subcomponents include a phrase-structure, a transformational and a lexical component.

\section{Phrase-Structure Rules}
(a) $\mathrm{NP} \rightarrow \mathrm{N}$ (Det) (Rel)
(b) $\mathrm{Rel} \rightarrow \mathrm{Mk}+\mathrm{S}$ 
(c) $\mathrm{S} \rightarrow \mathrm{NP}$ VP

(d) $\mathrm{VP} \rightarrow \mathrm{Cop}+(\mathrm{EMPH})+\mathrm{N}_{\mathrm{ABST}}$

Comment: there is no adjective in the base. Adjectives are the result of incorporation of Relative Marker into a suppletive form (see below).

\section{Transformational Rules}

$\begin{array}{lllll}\mathrm{N} & \mathrm{Mk} & \mathrm{NP} & \mathrm{Cop} & \mathrm{N}_{\mathrm{ABST}} \\ 1 & 2 & 3 & 4 & 5 \Rightarrow\end{array}$

(e) $\begin{array}{lllllll}\mathrm{T}_{1} \text { (obl) } & 1 & 2 & \varnothing & 4 & 5 & \text { (when N and NP are identical) }\end{array}$

(f) $\mathrm{T}_{2}$ (opt) $1 \quad \varnothing \quad\left\{\begin{array}{c}4+\text { Tone } \\ \varnothing\end{array}\right\} \quad 5$

Comment: lexical insertion for adjectives takes off obligatorily after $T_{1} . T_{2}$ yields all surface forms of non-adjectival relatives, with the null option selectable when $\mathrm{N}_{\mathrm{ABST}}$ is a qualifactive noun, i.e. ogologo, etc., but not when it is a cognate nominal (mma, njo, etc.)

(g) $\mathrm{T}_{3}$ (opt) $\mathrm{N} \quad$ EMPH $\quad \mathrm{N}_{\mathrm{ABST}}$

$$
\begin{array}{llll}
1 & 2 & 3 & \Rightarrow \\
& 2 & 3 & 1
\end{array}
$$

Comment: EMPH is obligatorily required for pre-posing to occur because the position of $\mathrm{N}_{\mathrm{ABST}}$ relative to $\mathrm{N}$ (the head) determines whether or not the abstract noun is emphatic.

Lexical Entries ((a) to (j) are partial)
(a) $\frac{\mathrm{N}}{n w a n y \grave{~}}$
(b) $\frac{\text { Cop }}{d i}$
(c) $\frac{\text { Cop }}{\text { mara }}$

(d)

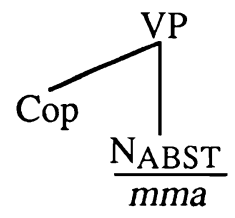


(e)

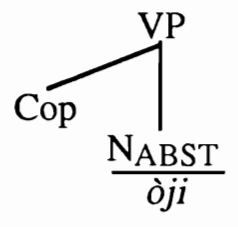

(f)

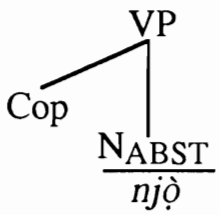

(i) $\frac{(\mathrm{EMPH}) \mathrm{N}_{\mathrm{ABST}}}{m k p u m k p u}$ (g)

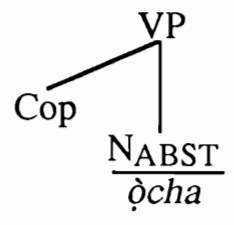

(j)

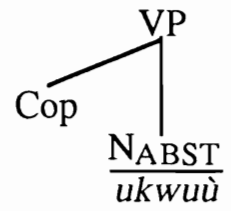

(k)

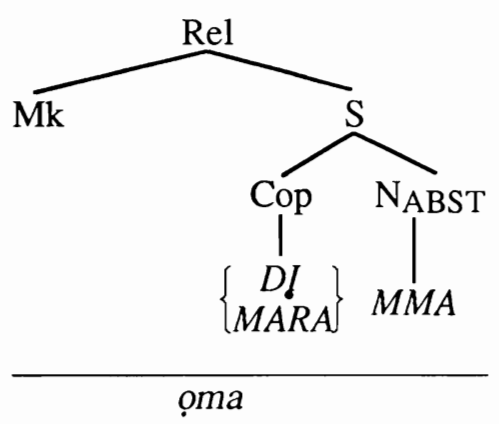

(m)

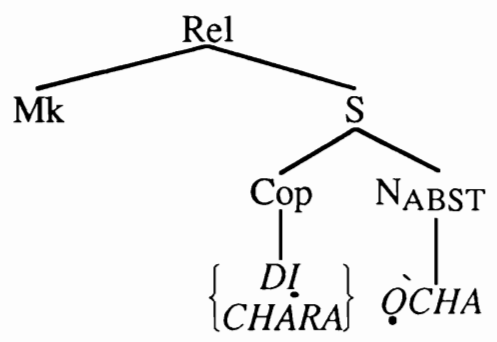

(l)

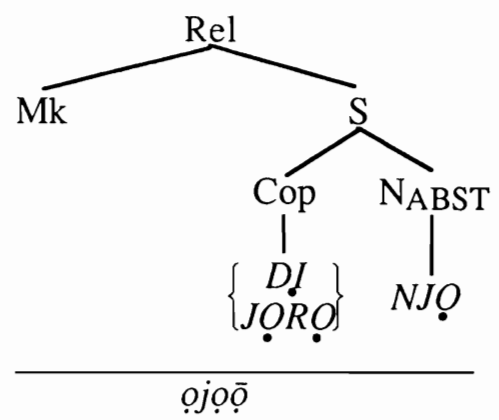

(n)

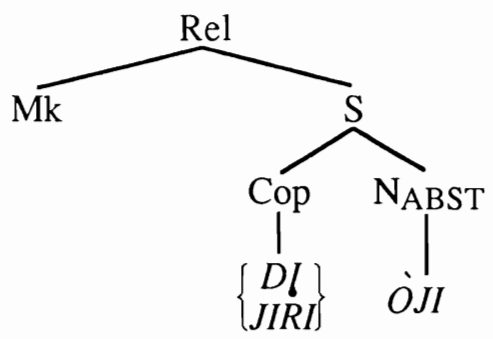

ọcha

$$
\text { ojĭ }
$$


(o)

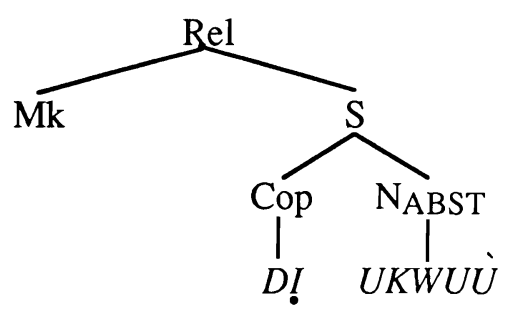

$u k w u$

(p)

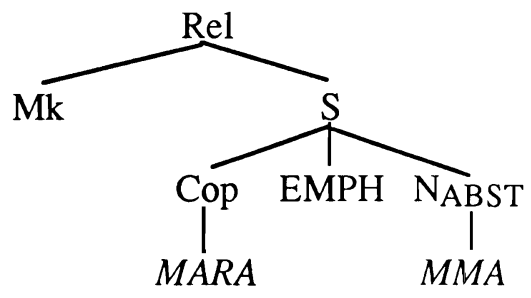

(q)

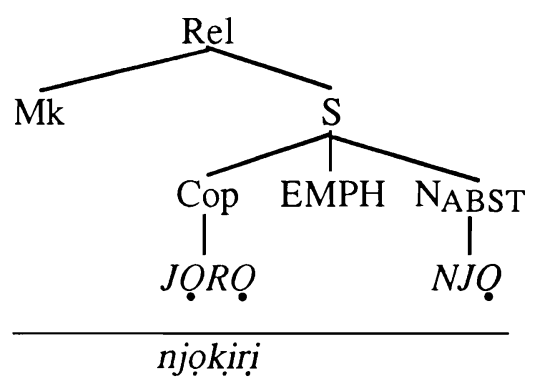

(r)

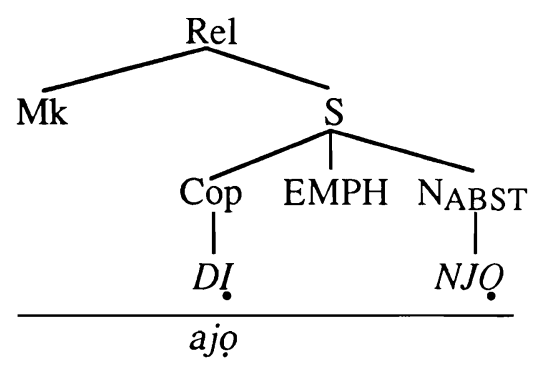

(s)

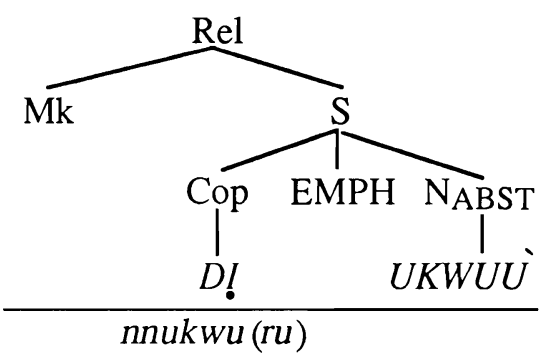

Comment: Cop is in the left environment of mma, njo, ọcha, $\partial j i$, and $u k w u u ̀$, but is not incorporated by them. Rather, it is incorported by oma, ojọo, ojin, and $u k w u$.This fact is indicated by the extent of the underline in each case. The wordsogologo and mkpumkpu optionally incorporate EMPH, indicated by '( )'. 


\section{Conclusions}

Basic-form adjectives in Igbo are derived from nouns, which are themselves derived from verbs by a simple morphological process (not discussed). More specifically, adjectives are predicates incorporating an abstract object nominal, a predicating copula, and a relative marker into a suppletive form. Adjectives in Igbo therefore do not exist in the base component, even though in a casual sense they are words in the language. That is, "adjective" is not a syntactic category in Igbo and as such is not needed for the formal grammatical description of the language. It is nevertheless a notional (semantic) category and therefore participates in perception and conception since it exists at a deep rather than a surface level. Carrell [1970] does not recognize this as she uses the category "Adj" in her syntactic derivations. On the other hand, Oluikpe [n.d.] is equivocal on this issue. He apparently recognizes the abstractness of adjectives when he derives them from underlying relatives (p. 66) though at the same time he incorporates "Adj" as a category in his lexical rules (pp. $41 \mathrm{ff}$ ).

Basic-form adjectives all incorporate two copulas, $d i$ and an appropriate cognate verb. This is with the exception of $u k w u$ which has no cognate verb. As a result, forms incorporating two copulas are ambiguous while $u k w u$ is not.

Again, with the exception of $u k w u$ adjectives consist of two pairs of antonyms, ocha 'white', 'bright' vs. ojī 'black', 'dark' and ọma 'beautiful', 'good' vs. ojọọ̄ 'ugly', 'bad'. The first pair is antipodal or taxonomic, while the second is polar or relative.

Basic-form adjectives invariably occur in post-nominal position like other nominal modifiers with the exception of qualifactive nouns. Polar adjectives can be emphasized, in which case they occur in a suppletive form. When suppleted, emphatic adjectives occur preferentially in the pre-nominal position. Antipodal adjectives cannot be emphasized since they are by nature absolute in their designation. It does appear, however, that a parallel notion of intensification can be achieved by way of an appropriate ideophonic periphrasis. While (with the exception noted) basic-form adjectives incorporate two copulas, emphatic forms appear to mandatorily incorporate only one. The reason for this is not yet clear. As a result of this they lack the form of ambiguity inherent in basic forms.

Qualifactive nouns such as ogologo behave partially like emphatic adjectives except that they bear emphasis only in the pre-nominal position whereas emphaticform adjectives still bear emphasis even in the rare situations when they occur post-nominally. Besides, qualifactive nouns can also be used in predicative position while emphatic-form adjectives often cannot.

There are gains to derive from both our formalism and our results. In the first place, an elegant account is given of aspects of the semantics of the Igbo adjective as well as its syntactic dispositions. Other gains include a reduction in the number of primitive syntactic categories as well as in the number of rules in the transformational component, especially "spelling out" rules. In addition, a greater unity is 
achieved between syntax and semantics by reducing interpretive semantic markers in the sense posited by Katz and Fodor [1963], Katz [1972], among others.

Finally, it will be interesting to find out how adjectives behave in other languages in comparison with our findings in this paper. Discussing adjectives and adjectival intensifiers in Hausa in relation to their syntactic peculiarities, Newman [1968:109] states as follows:

adj(ective) + int(ensifier) must follow the head noun whereas an adj without an int may occur either before or after the head noun, before being the normal position (intensifiers are underlined):
(1) rago fari $\underline{\text { fat }}$
'a snow white ram'
(2) *fari fat rago
(3) farin rago
'a white ram'
(4) rago fari
'a white ram (with contrastive emphasis on 'white')'

Newman's data is quite revealing. Intensifiers can occur directly with a colour adjective, unlike the situation in Igbo. As obtains in Igbo, position relative to head noun can signal emphasis. However, unlike Igbo the postnominal position is the emphatic position. As holds in Igbo, emphasis is signalled phonologically through suppletion. However, suppletive emphasis, unlike Igbo, involves reduction in phonological complexity. Finally, very much unlike Igbo and against normal expectations, a presumably taxonomic term is suppleted. Newman however adds (footnote) that "grammatically 'adjectives' in Hausa such as fari 'white' ... are really a subclass of noun." It will be interesting to further investigate the how's and why's associated with adjectives in these and other languages.

\section{REFERENCES}

Carrell, P.L. 1970. A Transformational Grammar of Igbo. West African Monographs, 8. Cambridge: Cambridge University Press.

Emenanjo, E.N. 1978. Elements of Modern Igbo Grammar. Oxford University Press, Nigeria.

Gruber, J.S. 1976. Lexical Structures in Syntax and Semantics. North-Holland Publishers, Ltd.

Katz, J.J. 1972. Semantic Theory. Harper, New York. 
Katz, J.J. and J.A. Fodor. 1963. "The structure of semantic theory." Language 39:170-210.

Newman, P. 1968. "Ideophones from a syntactic point of view.' Journal of West African Languages 2:107-117.

Oluikpe, B.O. n.d. Igbo Transformational Syntax. Africana Educational Publishers, Ltd. 